Марија Антић ${ }^{1}$

\title{
THE IMPORTANCE OF THE HYGIENIC-DIETARY REGIME IN THE TREATMENT OF INTESTINAL CANDIDIASIS
}

Marija Antić

\section{Сажетак}

Кандидијаза је гљивична инфекиија изазвана гљивицом која припада роду Саndida. Она је нормално присутна у телу, а у случају пада имунитета изазива опортунистичке инфекције.

Симптоми кандидијазе варирају у зависности од дела тела који је захваћен. Цревна кандидијаза доводи до низа непријатних симптома: надимање, гасови, горушица, грчеви у иревима, губитак апетита, надутост трбуха, промене столице од течне до тврде, хронични умор, главобоља, депресија. Фактори ризика који погодују развоју цревне кандидијазе су: стрес, неправилна исхрана и дуготрајна употреба неких лекова (антибиотици, кортикостероиди, имуносупресиви).

Након обављеног прегледа дијагноза се потврђује налазом кандиде у столици.

Лечене иревне кандидијазе може да потраје, јер инфекиија има тенденцију да се поново враћа. Кључ успешне терапије је промена начина исхране (антикандида дијета) и стила живота и, евентуално, увођење антигљивичних лекова.

У приказаном случају пачијенткињи је дијагностификована иревна кандидијаза. Фактори ризика којима је дуго била изложена су: професионални стрес, неправилна исхрана, физичка неактивност. Терапијски приступ базиран је на хигијенско-дијететском режиму и промени стила живота, едукацији и сарадњи паџијента. Након три месеиа дошло је до повлачења симптома, а миколошки преглед столице био је негативан.

\section{Summary}

Candidiasis is a fungal infection caused by the fungus belonging to the genus Candida. It is normally present in the body, and in the event of a fall in immunity, it causes opportunistic infections.

Symptoms of candidiasis vary depending on the part of the body that is affected. Intestinal candidiasis leads to a number of unpleasant symptoms: bloating, gasses, heartburn, cramps in the intestines, loss of appetite, abdominal flatulence, changes in the chair from fluid to hard, chronic tiredness, headache, depression. Risk factors that favor the development of intestinal candidiasis are stress, irregular nutrition and long-term use of some drugs (antibiotics, corticosteroids, immunosuppressants).

After the examination, the diagnosis is confirmed by the candida finding in the chair.

Treatment of intestinal candidiasis may take time because the infection has a tendency to return. The key to successful therapy is the change in diet (anti-candida diet) and lifestyle and, eventually, the introduction of antifungal drugs.

In the present case, the patient is diagnosed with intestinal candidiasis. Risk factors that have been exposed for a long time are: professional stress, improper diet, physical inactivity. The therapeutic approach is based on the hygienic-dietary regime and changes in the lifestyle, education and cooperation of the patient. After three months there was a withdrawal of the symptoms, and the mycological examination of the chair was negative.

\footnotetext{
${ }^{1}$ Др мед. Марија Антић, Дом здравља Брус, Краља Петра Првог 9, Брус, Србија.
} 
Кључне речи: иревна кандидијаза, лечење, антикандида дијета.
Key words: intestinal candidiasis, treatment, anti-candida diet.

\section{УВОД}

$\mathrm{K}$ андидијаза је гљивична инфекција изазвана гљивицом која припада роду Candida. Постоји више од двадесет врста кандиде, али инфекције код људи најчешће изазива Candida albicans.

Кандида се, као припадник нормалне микробне флоре тела, налази у усној шупљини, горњим деловима респираторног тракта, у цревима и, евентуално, у вагини код 10-14\% здравих особа. На здравој кожи може се наћи само изузетно. ${ }^{(1)}$ Она изазива такозване опортунистичке инфекције (инфекције које изазивају микроорганизми који су нормално присутни у телу, али у здравом организму не изазивају болест, већ само када дође до пада имунитета).

Симптоми кандидијазе варирају у зависности од дела тела који је захваћен. Кандидијаза може настати у устима, гастроинтестиналном тракту, гениталном тракту, на кожи, а уколико доспе у крвоток и рашири се по целом телу, тада говоримо о системској кандидијази.

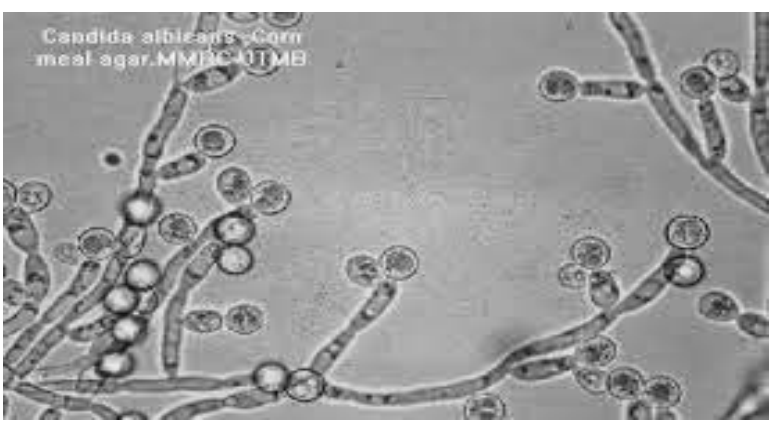

Слика 1. Изглед кандиде под микроскопом.

Цревна кандидијаза - У малом броју кандида је нормално присутна у цревима. Под дејством различитих фактора (антибиотици, кортикостероиди, имуносупресивни лекови, стрес, дијабетес, лоша исхрана) долази до њеног ширења и појаве кандидијазе. Најчешћи симптоми цревне кандидијазе су: надимање, гасови, горушица, грчеви у цревима, промене столице од течне до тврде, губитак апетита, надутост трбуха, слузава столица, анални свраб, наизменичан затвор и дијареја поред нормалних лабораторијских налаза и поред негативних ултразвучних и ендоскопских налаза. Може се јавити глад у налетима, нарочито неодољива жеља за слаткишима. Док код неких особа прекомеран раст кандиде доводи до губитка килограма, друге се суочавају са гојазношћу и потешкоћама да регулишу килажу. Прекомеран раст кандиде доводи и до накупљања течности у организму.

Кандида врсте, присутне у малом броју у скоро свакој столици, могу се у току антибиотерапије размножити у великом броју и бити један од узрочника псеудомембранозног колитиса. ${ }^{(2)}$

Кандида својим хифама прави мале пукотине у зиду црева, одакле несварени делови хране пролазе у крвоток. На тај начин настају алергија и интолеранција на храну. Такође, ствара мноштво разградних продуката који продиру у крвоток. Многи од ових продуката имају токсична дејства, па доводе до симптома као што су: главобоља, хронични умор, фибромиалгија, депресија, раздражљивост.

Чињеница је да је званична медицина тек у последње време признала кандидијазу као узрок многих тегоба и стања. Раније су лекари јако често проблеме које изазива претеран раст кандиде приписивали другим болестима, или их једноставно занемаривали.

Колонизацију и инвазију мукозе дигестивног тракта гљивама рода Candida често прати излучивање великог броја гљива и дијагноза се лако поставља налазом масе гљива у фецесу пацијента. ${ }^{(3)}$ Потребно је 
прегледати најмање три узастопна узорка столице да би се потврдило или искључило присуство кандиде.

Када је лечење кандиде у столици у питању, кључ успешне терапије је промена режима исхране (антикандида дијета) и основних животних навика. Једно од основних правила дијете за кандиду је избегавање уноса шећера у било ком облику. Поред дијете за кандиду, елиминацији ове гљивице помажу и бели лук, сода бикарбона, маслиново уље, кокосово уље, лимунов сок и неки други природни лекови. Што се тиче употребе антигљивичних лекова, у литератури се могу наћи различити подаци; док поједини аутори сматрају да се антигљивични лекови морају укључити одмах, други наглашавају да их треба укључити тек ако хигијенско-дијететски режим не доведе до жељеног резултата. Лечење кандиде у столици може да потраје и да исцрпи болесника, јер инфекција има тенденцију да се стално поново враћа.

\section{ЦИљ РАДА}

Циљ овог рада је указати на значај хигијенско-дијететског режима и промене начина живота у лечењу цревне кандидијазе, jep су пацијенти, а понекад чак и лекари, склони прескакању овог изузетно важног корака.

\section{ОПИС ПАЦИЈЕНТА ИЗ ПРАКСЕ}

Пацијенткиња стара 34 године се августа 2017. године јавља изабраном лекару са следећим тегобама: горушица, надимање у стомаку, надутост трбуха (нарочито након конзумирања хлеба, пецива и слаткиша), немогућност регулисања телесне масе, хронични умор. Столица је углавном уредна. Наведене тегобе има неколико месеци уназад и није се јављала лекару због презаузетости послом. Од придружених болести наводи екцем који се повремено јавља на рукама, као и депресивне епизоде и повремене нападе анксиозности (шест месе- ци уназад је на терапији антидепресивима коју је прописао психијатар). Негира друге болести од значаја током живота. У породичној анамнези наводи да је мајка пре пет година имала акутни панкреатитис и пар месеци након тога оперисала жучну кесу. Отац напрасно преминуо у 39. години, био је срчани болесник.

При прегледу пацијенткиња је доброг општег стања, ТА 110/75, налаз на срцу и плућима уредан. Абдомен у равни грудног коша, мек, неосетљив на површну и дубоку палпацију. Пацијенткиња је висока $170 \mathrm{~cm}$, тешка $78 \mathrm{~kg}$, ВMI 27. Наводи да се јако дуго бори са вишком килограма, али не истрајава у дијети због напада глади и неодољиве жеље за слаткишима. Пушач је петнаест година уназад, повремено конзумира алкохол (последњих месеци не, због психијатријске терапије). Бави се стресним послом (менаџер хотела) и због природе посла живи у хотелу на планини. По завршеном прегледу је добила упут за лаборатијски преглед крви и урина, преглед столице на бактерије, гљивице и паразите, као и за ултразвучни преглед абдомена.

После десетак дана долази на контролни преглед и доноси медицинску документацију коју је прикупила при допунским прегледима, а који изгледају овако:

- Лабораторијски преглед крви: Wbc 7,4, Lym 3,2, Mid 0,4, Gra 3,8, Rbc 4,05, Hgb 121, Plt 255, SE 14/30, CRP 3,5, Glu 4,86, Hol 4,7, Trig 1,5, SGOT 20,5, SGPT 25,7, Urea 4,0, Kreatinin 74, Bil. dir 2,2, Bil. uk 11,1, alfa amil 53,2, Fe 12,6.

- Општи преглед урина: 6-8 Le, мало епителних ћелија, мало кристала Са-оксалата.

- ЕНО абдомена: У цревима нешто веће гасне колекције. Остали налаз уредан.

- Бактериолошки и паразитолошки преглед столице уредан.

- Миколошки преглед столице: Candida sp. у маси. 
На контролном прегледу пацијенткиња наводи да се консултовала и са гастроентерологом (приватно) који је предложио да одмах започне са хигијенско-дијететским режимом. Од дијететских суплемената саветовао је препарате цинка и Ц витамина. Након три месеца требало би поновити миколошки преглед столице и, у зависности од резултата, евентуално укључити пробиотик, а антимикотску терапију тек уколико претходна два корака не дају резултате. Такође је обавила и гинеколошки преглед, налаз је уредан.

Изабрани лекар се слаже да са такозваном „,антикандида“ дијетом пацијенткиња започне одмах. Пацијенткиња је прилично едукована и спремна на сарадњу, што изабраном лекару у овом случају знатно олакшава приступ.

Током наредна три месеца пацијенткиња је била на хигијенско-дијететском режиму који је подразумевао искључивање из исхране следећих намирница:

- Намирнице које садрже шећер и све угљене хидрате: слаткиши, сокови, мед, алкохолна пића;

- Све житарице и све махунарке;

- Све врсте воћа и сушено воће;

- Кромпир, печурке и коренасто поврће (цвекла, шаргарепа и сл.);

- Млеко и млечни производи (осим домаћег кефира и јогурта);

- Квасац, маргарин и куповни сосови (кечап, мајонез);

- Сухомеснати и конзервирани производи јер садрже глутаминате, нитрите и мноштво других адитива;

- Мешавине зачина које садрже глутаминате и екстракте квасца;

- Индустријски прерађене намирнице свих врста;

- Рафинисана биљна уља (сунцокретово, кукурузно, сојино).

Храна која је била дозвољена за време антикандида дијете:
- Све месо, изнутрице и домаће сушено месо (сланина, пршута и кобасице);

- Поврће које расте изнад земље (осим печурака);

- Риба и остала храна из мора;

- Лакто-ферментисане намирнице (домаћи кефир, јогурт и домаћи кисели купус);

- Јаја (домаћа) и масти (маслац, пилећа, пачја, говеђа и свињска маст);

- Хладно пресована уља - кокосово, маслиново, ланено и сусамово уље;

- Лук, бели лук, куркума, ђумбир, зачинско биље;

- Лимун, грејпфрут и авокадо;

- Супе од костију, месне, кокошје, рибље и супе од поврћа;

- Смути - кашасти сокови од поврћа и здравих масноћа;

- Орашасти плодови и семенке у малим количинама (кикирики не);

- Кокосово брашно, кокосово млеко, незаслађени какао прах;

- Хељдино брашно (за припрему хлеба и тестенина);

- Вода, биљни чајеви, лимунада.

Пример дневног јеловника:

- Доручак: два пржена јаја, хлеб од хељдиног брашна (без квасца и соли, са мало соде бикарбоне);

- Ужина: шака бадема и лешника;

- Ручак: динстана пилетина са домаћим сосом од парадајза, салата од купуса, хлеб од хељдиног брашна;

- Вечера: салата направљена од ренданог краставца, јогурта, белог лука и мало маслиновог уља.

Од напитака је пацијенткиња конзумирала: обичну и минералну воду, лимунаду без шећера, кафу, какао и биљне чајеве без шећера. Узимала је 1-2 кашике кокосовог уља дневно и препарате цинка.

Свакодневно је упражњавала неки вид умерене физичке активности у трајању од 
најмање пола сата - трчање, брза шетња или вежбе у теретани.

Предвиђено време трајања овог хигијенско-дијететског режима било је три месеца, током којих је пацијенткиња била изузетно дисциплинована. На контролном прегледу наводи да су раније присутни симптоми на које се жалила бивали све слабије изражени, и да су се на крају сасвим повукли. Контролни миколошки преглед столице урађен је након три месеца и био је негативан.

Пацијенткиња наводи да током дијете није била гладна, јер се хране није било потребно одрицати, већ је мудро бирати. У самом почетку је имала јаку потребу за слаткишима, али се временом навикла на нови режим исхране. Иако није гладовала, хигијенско-дијететски режим је резултовао и регулисањем телесне масе, тако да је пацијенткиња изгубила десетак килограма и приближила се својој идеалној телесној маси.

Пацијенткињи је наглашено да дијета против кандиде подразумева релативно трајне промене у исхрани, како би се спречио поновни развој инфекције. Дат је савет да постепено уводи намирнице које су биле забрањене, почевши од зелених јабука, и да затим настави са увођењем по једне намирнице недељно. Уколико примети да јој нека намирница не прија, неопходно је одмах поново искључити из исхране. Такођ је наглашено да, колико год је могуће, избегава бели шећер, јер он доказано штети и здравим особама. Контролни прегледи подразумеваће и обавезне прегледе столице на гљивице.

\section{ДИСКУСИЈА}

Континуирана изложеност факторима ризика може довести до неконтролисаног размножавања кандиде, која је иначе нормално присутна у људском организму. У приказаном случају ти фактори ризика су: професионални стрес (присутан више година уназад), нередовна и неправилна ис- храна, као и седентарни начин живота. Све то је узроковало слабљење имуног система пацијенткиње и, коначно, неконтролисано размножавање кандиде у цревима. Пацијенткиња је због пословних обавеза и специфичног начина живота одлагала одлазак лекару. При томе је појава симптома од стране нервног система (анксиозност, депресивне епизоде) одводе најпре психијатру. С обзиром на то да се поменути симптоми могу јавити у склопу клиничке слике цревне кандидијазе, пре увођења терапије од стране психијатра требало је спровести третман против кандиде.

Цревна кандидијаза још увек често бива непрепозната, те се симптоми које проузрокује приписују другим гастроинтестиналним болестима, а пацијенти бивају подвргавани непотребним испитивањима и неадекватној терапији. И када се дође до тачне дијагнозе, важност хигијенско-дијететског режима се углавном неоправдано ставља у други план, јер су пацијенти често неспремни да се подвргну специфичном режиму исхране. Иако неки аутори сматрају да је неопходно антигљивичне лекове увести одмах, важно је едуковати пацијенте и указати им на значај дијете, промене начина живота и јачање природних одбрамбених снага организма.

Након успостављања дијагнозе цревне кандидијазе неопходно је урадити и гинеколошки преглед код жена, због могућности истовремене вагиналне кандидијазе. Такође је неопходно извршити преглед усне дупље, jep је цревна кандидијаза често удружена са орофарингеалном.

У приказаном случају пацијенткиња је била изузетно спремна на сарадњу, што је довело до повољног исхода у предвиђеном року.

\section{ЗАКЈЬУЧАК}

Цревна кандидијаза је све чешћи проблем данашњице, углавном због савременог начина живота који резултира слабље- 
њем имунитета појединаца. Важно је да при првом прегледу изабрани лекар препозна симптоме и тиме избегне непотребно губљење времена. Лечење ове болести је изазов за изабраног лекара због тенденције инфекције да се изнова враћа. Неопходно је едуковати пацијента и указати му на значај сарадње у спровођењу хигијенскодијететског режима и промене стила живота. Уколико овакав третман не буде дао резултате у току три месеца, у терапију је неопходно увести и антигљивичне лекове.

\section{ЛИТЕРАТУРА:}

1. Каракашевић Б. и сар. Микробиологија и паразитологија. Медицинска књига Београд-Загреб, 1980; стр. 952.

2. Теодоровић Ј. и сар.

Гастроентерологија. Exelsior, Београд, 1998; 2: 343.

3. Тасић С, Пешић С. Гљивичне инфекције - дијагноза и могућности терапије. Медицински факултет Ниш, 2006; 39 .
4. Мунтанола-Цветковић М. Општа микологија. НИРО Књижевне новине. Београд. 1987.

5. Митровић С. Фактори патогености гљива рода Candida. Докторска дисертација, Медицински факултет Београд, 1994.

6. Николић М. Исхрана код инфекције

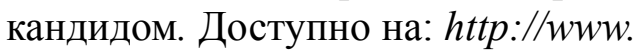
stetoskop.info/Ishrana-kod-infekcijekandidom-1376-c15-content.htm, прегледано: 6. 2. 2018.

Контакт: Др мед. Марија Антић, доктор медицине на специјализацији из опште медицине, 18000 Ниш, ул. Мокрањчева 94/46, тел: 0631179122, e-mail: opetuformi@gmail.com 